Tomasz Figlus

\title{
Geneza, rozwój i zanik Wiączynia \\ Próba rekonstrukcji geograficzno-historycznej osadnictwa w aspekcie przemian zagospodarowania przestrzennego i rozplanowania wsi
}

\begin{abstract}
Artykuł przedstawia wyniki badań dotyczących nieistniejących współcześnie wsi Wiączyń Polny i Leśny, na terenie których na początku XIX w. powstały nowe kolonie pruskie. Zbadano rozwój osadnictwa w średniowieczu i dokonano analizy zagospodarowania w okresie nowożytnym na tle stosunków prawno-własnościowych. Obie wsie pojawiły się w źródłach historycznych w XIV w. i wchodziły w skład dóbr królewskich. Przez większość czasu swego funkcjonowania były dzierżawione przez przedstawicieli szlachty, przy czym najdłużej były w posiadaniu rodu Lasockich. Były to stosunkowo niewielkie osady, zamieszkane przez chłopów pańszczyźnianych. W Wiączyniu były zlokalizowane: karczma i folwark, obejmujący dwór i zabudowania gospodarcze, w tym budynek browaru. W pracy dokonano również próby rekonstrukcji rozplanowania wsi i zbadano proces sukcesji osadnictwa. Wiączyń Polny miał formę nieregularnej wsi drogowo-placowej, a Wiączyń Leśny miał charakter wsi wielodrogowej. W wyniku kolonizacji pruskiej na ich miejscu powstały nowe wsie: Nowosolna, Wiączyń Dolny, Górny i Nowy. Były rozplanowane w postaci regularnych wsi liniowych, przy czym Nowosolna przyjęła formę unikatowej struktury, składającej się z ośmiu promienistych dróg wychodzących z centrum układu.
\end{abstract}

Słowa kluczowe: osadnictwo, wieś, geografia historyczna, morfogeneza, zagospodarowanie przestrzenne, rozplanowanie, układ przestrzenny, Wiączyń.

\section{Wprowadzenie}

Na przełomie XVIII i XIX na obszarze objętym współczesnymi granicami Łodzi i w sąsiedztwie miasta administracja pruska prowadziła intensywną akcję osadniczą. W jej efekcie w obrębie przejętych na własność dawnych dóbr królewskich i kościelnych utworzono nowe osady wiejskie. Wśród polskich wsi pańszczyźnianych pojawiły się kolonie czynszowe, o odmiennym rozplanowaniu, zamieszkiwane przez ewangelików niemieckiego pochodzenia. W ten właśnie sposób na terenie zajętym pierwotnie przez dwie osady: Wiączyń Polny i Wiączyń Leśny rozmierzono w ciągu kilku lat od podstaw nowe wsie pruskie: 
Nowosolną oraz Wiączyń Dolny, Górny i Nowy. Znane w źródłach od XIV w. wsie monarsze przestały natomiast istnieć. Dotychczasową zabudowę wyburzono, a ludność autochtoniczna została przesiedlona. Rozwinęły się na tym miejscu nowe układy przestrzenne zasiedlone przez imigrantów, pochodzących głównie z Wirtembergii. Po drugiej wojnie światowej doszło do polonizacji obu jednostek osadniczych, lecz ich rozplanowanie zachowało w znacznej mierze swój unikatowy charakter. Z dniem 1 stycznia 1988 r. dawne wsie Nowosolna o powierzchni 1576,93 ha oraz Wiączyń Górny o powierzchni 342,53 ha zostały włączone w granice administracyjne miasta Łodzi (zob. Stępniewski, Szambelan 2009) ${ }^{1}$. Wiączyń Dolny i Nowy znajdują się natomiast dzisiaj poza Łodzią, w gminie Nowosolna, w powiecie łódzkim wschodnim.

W dotychczasowej historiografii niewiele miejsca poświęcano osadnictwu poprzedzającemu bezpośrednio rozwój tzw. kolonizacji fryderycjańskiej i jej kontynuacji na terenie Prus Południowych. Koncentrowano głównie uwagę na genezie nowych kolonii, ich zagospodarowaniu i organizacji przestrzennej (np. Zimmermann 1915, Kossmann 1942, Heike 1979, Kotkowski 1991, Koter 1994, Schiewe 2000, Schöller 2009, Woźniak 2013, 2015). Fakt powstania wspomnianych wsi pruskich na miejscu wcześniej istniejących osad królewskich nie umknął co prawda uwadze badaczy, ale zagadnienie to zostało potraktowane marginalnie. Przejawem tego były niekiedy błędy interpretacyjne w zakresie lokalizacji i wzajemnych relacji przestrzennych, co prawdopodobnie wynikało z pozornej ciągłości toponimicznej. W niektórych przypadkach utożsamiano historyczne wsie Wiączyń Polny i Leśny wyłącznie z obszarem powstałych w XIX w. osad Wiączyń Górny, Dolny i Nowy, pomijając zupełnie teren Nowosolnej. Bardzo ogólnie omówiono do tej pory dzieje obu zlikwidowanych osad w okresie staropolskim, czego wyrazem mogą być jedynie krótkie wzmianki na ich temat $\mathrm{w}$ literaturze mediewistycznej dotyczącej badanego obszaru (np. S. i S.M. Zajączkowski 1970, s. 168, Malinowska 2001, s. 54-55). Brakowało jak dotąd opracowania, które stanowiłoby próbę kompleksowej rekonstrukcji geograficzno-historycznej rozwoju obu nieistniejących już dziś wsi monarszych oraz analizy zjawiska sukcesji osadniczej. Stanowiło to dla autora asumpt do podjęcia się tego zadania badawczego. Celem artykułu jest zatem omówienie genezy obu Wiączyniów na tle stosunków prawno-własnościowych,

\footnotetext{
${ }^{1}$ Uchwała Rady Narodowej Miasta Łodzi nr XXVII/161/87 z dnia 29 czerwca 1987 r. w sprawie zmiany granic miasta Łodzi, Monitor Polski, nr 25, poz. 205, z dnia 4 września 1987 r.; Zarządzenie nr 37/87 Prezydenta Miasta Łodzi z dnia 30 września 1987 r. w sprawie szczegółowego opisu granic miasta Łodzi, Dziennik Urzędowy Województwa Łódzkiego nr 14 z dnia 30 października 1987 r.
} 
zbadanie ich zagospodarowania w całym okresie nowożytnym i przemian w zakresie rozplanowania poprzez porównanie układów ruralistycznych z końca XVIII w. oraz z początku XIX w. Dodatkowym celem jest także określenie okoliczności zaniku osadnictwa i rozwoju nowych struktur przestrzennych o odmiennym charakterze prawnym, społeczno-kulturowym i kompozycyjnym (szerzej: Figlus 2016). Realizacji wyszczególnionych celów służyła kwerenda źródeł historycznych w postaci archiwalnych dokumentów, materiałów opisowych i kartograficznych. Pod kątem powstania i rozwoju wsi do początków XVI w. analizie poddano zapiski w łęczyckich księgach sądowych i ziemskich. W odniesieniu do sytuacji prawno-własnościowej wykorzystano wybiórczo wpisy do Metryki Koronnej dotyczące nadania i rozgraniczenia dóbr oraz Liber beneficiorum Jana Łaskiego. Rekonstrukcja przemian zagospodarowania wsi możliwa była dzięki szczegółowemu zbadaniu treści dostępnych lustracji królewszczyzn z lat 1565, 1616-1620, 1628-1632, 1659-1665 i 1789 (zob. Żytkowicz 1973, Chłapowski, Dygdała 2005), uzupełnionych wybranymi rejestrami poborowymi. Zmiany rozplanowania wsi i wzajemne relacje przestrzenne form osadniczych omówiono na podstawie analizy planów i map dostępnych w Archiwum Głównym Akt Dawnych w Warszawie oraz zasobów kartograficznych Biblioteki Uniwersytetu Warszawskiego.

\section{Zarys rozwoju osadniczego Wiączynia w średniowieczu}

Dokładne ustalenie genezy Wiączynia jest trudne do ustalenia w świetle zachowanego materiału źródłowego. Istnienia wsi nie odnotowują bowiem żadne źródła pisane, zarówno dokumentowe, jak i opisowe $\mathrm{z}$ wczesnego średniowiecza. Pierwsza wzmianka na temat Wiączynia pochodzi z 1389 r. Nie odnosi się ona jednak do momentu „narodzin” osady, tj. nie wskazuje jednoznacznie na metrykę historyczną i nie wyjaśnia okoliczności powstania wsi. Cezura ta stanowi zatem terminus ante quem, a więc moment dziejowy, przed którym wieś już funkcjonowała w strukturze sieci osadniczej. Trudno określić, jak wiele czasu minęło od powstania osady do pojawienia się pierwszej zapiski. W sukurs mogą przyjść badania archeologiczne, które mogłyby przesunąć wstecz metrykę wsi. Przy obecnym stanie wiedzy trudno jednak dokonać takiego wnioskowania, nie tylko $\mathrm{w}$ sensie chronologicznym, ale również w aspekcie ustalenia ciągłości procesów osadniczych. Pierwsza wzmianka na temat Wiączynia pochodzi z ksiąg sądowych łęczyckich. Dotyczy ona procesu, w którym stronami byli Johannes Kopacz i Adam de Beldowo. Wśród pięciu świadków pojawia się w tym doku- 
mencie postać Ligaszcza piszącego się z miejscowości o nazwie Wiancza ${ }^{2}$. Tytułem uzupełnienia warto dodać, że pod koniec XIV w. odnotowujemy radykalny wzrost liczby punktów osadniczych, które można po raz zidentyfikować w świetle materiału źródłowego. Nie jest to jednak tożsame z intensyfikacją procesu rozwoju osadnictwa, lecz powstaniem i upowszechnieniem nowego typu źródeł dokumentowych, ze szczególnym uwzględnieniem ksiąg ziemskich i grodzkich. Zapiski na temat Wiączynia pojawiały się odtąd systematycznie na kartach ksiąg sądowych, każdorazowo jednak w różnych, zniekształconych formach toponomastycznych. I tak wzmianka z 1416 r. odnosi się do sprawy, w której stronami byli: Andreas de Droszanczyno i Florian, kmieć de Wanczen. Z 1417 r. pochodzi zapiska sądowa wymieniająca Floriana de Wanczyen, natomiast z 1418 r. odnajdujemy informację o sporze Klemensa, zarządcy Kurowic (Curouicze), z Grzegorzem, zarządcą Wiączynia (Gregorio procuratore de Waczen $)^{3}$.

Pierwsze dane źródłowe stwierdzające istnienie dwóch osad wiączyńskich uzyskujemy na podstawie informacji pochodzących z ksiąg ziemskich łęczyckich (Malinowska 2001, s. 54, Nowak 2003). W 1418 r. Piotr z Tura, podstoli łęczycki, w ugodzie ze swymi bratanicami uzyskał potwierdzenie posiadania obu wsi wiączyńskich ${ }^{4}$. Potwierdzenie funkcjonowania dwóch wsi o wspólnym członie nazewniczym daje wpis do Metryki Koronnej, datowany na $1439 \mathrm{r}$. Zgodnie z jego treścią król Władysław III dokonał zapisu in Maiori et Minori Wyanczinye i potwierdził przekazanie ad vitae tempora obu wsi królewskich na rzecz Jakuba z Baranowa, podstolego sandomierskiego i starosty łęczyckiego ${ }^{5}$. Poddane analizie osady Wiączyń duplex jako wsie monarsze położone w województwie łęczyckim od połowy XV w. pozostawały długotrwale w tenucie zamożnego i wpływowego rodu Lasockich - właścicieli miasta Brzeziny, posiadającego w strukturze administracyjnej okresu przedrozbiorowego status ośrodka powiatowego. Związanego $\mathrm{z}$ nimi zapisu dzierżawnego dokonano po raz pierwszy w 1441 r. na rzecz Mikołaja Lasockiego, pełniącego w tym czasie funkcję dziekana krakowskiego i prepozyta łęczyckiego, a od 1449 r. biskupa

\footnotetext{
${ }^{2}$ Księgi sądowe łęczyckie od 1385 do 1419 (dalej: PKL), cz. 1, [w:] Teki A. Pawińskiego, t. 3, Warszawa 1897, nr 1203, s. 112.

${ }^{3}$ PKL, cz. 2, [w:] Teki A. Pawińskiego, t. 4, Warszawa 1897, nr 2777, s. 323; nr 2952, s. 344; nr 3028, s. 353.

${ }^{4}$ Zob. Archiwum Główne Akt Dawnych w Warszawie (dalej: AGAD), Księgi ziemskie łęczyckie, ks. 6, k. 276.

${ }^{5}$ Matricularum Regni Poloniae Summaria (dalej: MRPS), cz. 2, wyd. T. Wierzbowski, Warszawa 1907, nr 47, s. 103.
} 
włocławskiego ${ }^{6}$. Pochodził on z drobnoszlacheckiego rodu Dołęgów, dziedziców wsi Lasotki pod Dobrzyniem nad Wisłą. Był jednym z najbliższych współpracowników króla Władysława Jagiełły i Władysława Warneńczyka, podejmując się $\mathrm{w}$ czasie ich panowania odpowiedzialnych misji dyplomatycznych (Witczak 1971).

Należące formalnie do monarchy wsie wiączyńskie, stanowiące odizolowany przestrzennie klucz majątkowy, otoczony był zewsząd przez dobra szlacheckie i kościelne (zob. też: Sobczak 1955, Figlus 2015). Wiączyń Leśny sąsiadował z Mileszkami, Małczewem, Paprotnią, Lipinami, Bedoniem oraz dobrami należącymi do kapituły krakowskiej. Wiączyń Polny graniczył z Mileszkami, Stokami i Sikawą, Kalonką, Barchówką, Byszewami oraz Moskwą ${ }^{7}$.

Niezwykle istotne z punktu widzenia rozwoju Wiączynia wydaje się również umiejscowienie wsi w kościelnej strukturze terytorialno-organizacyjnej ukształtowanej w średniowieczu. Wiączyń od początków swego istnienia, a następnie funkcjonujący w formie układu podwójnego (Vyaczenye duplex, maius et minus), położony był na terenie parafii Mileszki, w obrębie dekanatu szczawińskiego, usytuowanego w archidiakonacie łęczyckim. Na podstawie Liber beneficiorum Jana Łaskiego można stwierdzić, że dziesięcina z Wiączynia Leśnego i Polnego wykazywała dwojaki charakter w zależności od form użytkowania gruntów. Jedna $\mathrm{z}$ nich, post agros praediales et tabernatores ( $\mathrm{z}$ pól folwarcznych i stanowiących uposażenie karczmarzy), trafiała do plebana parafii w Mileszkach. Druga część, post agros cmethonales (z pól chłopskich), przekazywana była na rzecz opata trzemeszeńskiego w Kazimierzu nad Nerem ${ }^{8}$, co może stanowić argument, jak twierdzi J. Malinowska (2001, s. 55), przemawiający na korzyść hipotezy zakładającej przesunięcie metryki historycznej wsi do XIII w.

\section{Przemiany zagospodarowania przestrzennego wsi na tle stosunków osadniczych w XVI i XVII wieku}

Na początku XVI w. osady królewskie w północnej i środkowej części powiatu brzezińskiego (niewchodzące w skład starostwa inowłodzkiego) nadal pozostawały w tenucie rodu Lasockich. Potwierdza to dokument wystawiony

\footnotetext{
${ }^{6}$ MRPS, cz. 2, nr 55, 57-59, s. 104.

${ }^{7}$ Zob. Lustracja województw wielkopolskich i kujawskich 1659-1665 (dalej: LWWK 1659-1665), cz. 2: województwa sieradzkie, łęczyckie, brzesko-kujawskie, inowrocławskie i ziemia dobrzyńska, wyd. Z. Górski, J. Pakulski, A. Tomczak, Toruń 1996, s. 212.

${ }^{8}$ Jana Łaskiego arcybiskupa gnieźnieńskiego Liber beneficiorum archidiecezji gnieźnieńskiej, wyd. J. Łukomski, J. Korytkowski, t. 2, Gniezno 1881, s. 383-384.
} 
przez władcę w 1528 r., zgodnie z którym Wyanczenye, Szeligi i Szczawin uzyskał w dzierżawę Stanisław Lasocki, podkomorzy poznański oraz starosta i wojski rawski ${ }^{9}$. Zgodnie z zapisami ujętymi w Metryce Koronnej z 1547 r., decyzją króla Zygmunta I, podjętą w Piotrkowie, dobra monarsze, w tym Viączen leszny i polny, podobnie jak Szeligi i Szczawin, na zasadach niedziału były w rękach Jakuba Lasockiego, kasztelana inowłodzkiego, a także Krzysztofa, późniejszego starosty gostyńskiego oraz potomstwa Stanisława, podkomorzego łęczyckiego ${ }^{10}$. W tym samym roku zatwierdzono działy rodzinne pomiędzy Lasockimi i przekazano na dożywocie oba Wiączynie Jakubowi Lasockiemu i jego żonie Annie oraz ich synowi Mikołajowi ${ }^{11}$. Warto podkreślić, że dane lustracyjne z połowy XVI w. wskazują, że dobra królewskie kontrolowane wcześniej przez rodzinę Lasockich, tj. osady Szczawin i nieistniejącą już dziś wieś Szeligi (zlokalizowaną między Dobrą, Glinnikiem i Szczawinem), dzierżył Jan Piaskowski, miecznik łęczycki, któremu odstąpiono na dożywocie obie wsie w 1554 r. ${ }^{12}$

$\mathrm{Na}$ podstawie informacji pochodzących z lustracji królewszczyzn z lat 1564-1565 można stwierdzić, że we wsi Lesni Wiaczeń odnotowano 4,5 łanu ziemi. Z każdego łanu płacono po trzy korce owsa miary brzezińskiej (po 6 groszy, dalej gr) oraz uiszczano rentę w formie naturaliów obejmującą po dwie kury (po 1 gr), 20 jaj (po 1 denar, dalej den) i dwa sery (po 9 den). Oprócz tego ustalono zobowiązanie w postaci czynszu wołowego wynoszącego 1 floren (fl). Na podstawie prowentu stacyjnego wyżej omienionego (w postaci 13 korców owsa, dziewięciu kur, półtorej kopy jaj, dziewięciu serów i wołowego) zgromadzono dochód w wysokości 4 fl, 9 gr i 8 den. Dla porównania Polny Wiaczeń obejmował cztery łany poddane lustracji. Warto dodać, że identyczny stan powierzchni gruntowej obu wsi określa również kolejna, niewydana drukiem lustracja z 1569 r. $^{13}$ Zobowiązania feudalne były analogiczne jak w Wiączyniu Leśnym, z zastrzeżeniem wołowego, który wynosił 1 fl i 10 gr. Na podstawie stacyjnego obejmującego 12 korców owsa, osiem kur, jednej kopy i 20 jaj oraz ośmiu serów, a także wołowego uzyskano łącznie dochód $4 \mathrm{fl}, 8 \mathrm{gr}$ i $8 \mathrm{den}^{14}$.

Dodatkowych danych uzupełniających na temat Wiączynia w drugiej połowie XVI w. dostarcza lektura rejestrów poborowych, wydanych drukiem przez

${ }^{9}$ MRPS, cz. 4/1, wyd. T. Wierzbowski, Warszawa 1910, nr 5359, s. 316.

${ }^{10}$ MRPS, cz. 4/1, nr 7969, s. 458; Boniecki A. (dalej: Boniecki), Herbarz Polski, t. 13, Warszawa 1909, s. 388-393.

${ }^{11}$ MRPS, cz. 4/1, nr 8062, s. 462.

${ }^{12}$ AGAD, Metryka Koronna (dalej: MK) 86, f. 200v.

${ }_{13}$ AGAD, Archiwum Skarbu Koronnego (dalej: ASK) XLVI, 103d, k. 320.

${ }^{14}$ AGAD, MK XVIII, 5, f. 262v-263; Lustracja województw wielkopolskich i kujawskich 1564-1565, cz. 2, wyd. A. Tomczak, Bydgoszcz 1963, s. 202-204. 
A. Pawińskiego (1883). Rejestr dla województwa łęczyckiego datowany jest na 1576 r., przy czym liczba osadników odnosi się do 1552 r. W przypadku obu Wiączyniów potwierdzony jest status villae regales z uwzględnieniem dzierżawy Jakuba Lasockiego. Odnotowana powierzchnia jest przy tym powiększona o pozostałe nadziały gruntów nieuwzględnione w lustracjach z podobnego okresu. W odniesieniu do Wiączynia Dolnego, który należy utożsamiać z Wiączyniem Polnym, wykazano w rejestrze z 1576 r. 8,5 łanu, natomiast w Wiączyniu Małym (Wiaczeni minor) utożsamianym z Wiączyniem Leśnym podano powierzchnię 10 łanów. W Wiączyniu Polnym (Dolnym) odnotowano jednego zagrodnika, trzech karczmarzy i sześciu rzemieślników (artifices). Analogicznie w Wiączyniu Leśnym (Małym) wzmiankowano dwóch zagrodników, czterech karczmarzy i czterech rzemieślników. Dysponujemy zatem potwierdzenie funkcjonowania w tym czasie osad karczemnych $\mathrm{w}$ strukturze przestrzennej wsi. Wiadomo również, że Wiączyń obejmował w tym okresie grunty folwarczne (agros praediales). W przypadku obu wsi rejestr wskazuje na identyczną liczbę 24 osadników (dla 1552 r.). Można przypuszczać, że analizowane osady wiączyńskie nie przeszły lokacji na prawie niemieckim, w przeciwieństwie do dzierżawionych uprzednio przez Lasockich wsi Szeligi i Szczawin, w których znajdowały się sołectwa i przynależne do nich grunty, odnotowane w rejestrach poborowych $^{15}$.

Podczas lustracji królewszczyzn z 1620 r. wsie Wiączyń Polny i Leśny były w posiadaniu Pawła Lasockiego, h. Dołęga z Brzezin, późniejszego podczaszego lubelskiego i jego żony Zofii z Zalesia. Uzyskali oni prawa dzierżawne na podstawie przywileju króla Zygmunta III Wazy z 3 marca 1618 r. ${ }^{16}$ Rok wcześniej król zezwolił podskarbiemu koronnemu i wojewodzie podlaskiemu Stanisławowi Warszyckiemu na wykup tych wsi z rąk Małgorzaty, wdowy po chorążym łęczyckim Janie Lasockim ${ }^{17}$. W świetle analizowanej lustracji Wiączyń Leśny zajmował 12 łanów, czego 10 półłanków osiadłych. Lustratorzy podkreślili $\mathrm{w}$ trakcie przeprowadzonej rewizji znaczne opustoszenie gruntów pochodzące z czasów przodków dzierżawcy. Wykazano obecność 14 kmieci, gospodarujących częściowo na łanach osiadłych, a częściowo pracujących na gruntach folwarcznych. Kmiecie zobowiązani byli do czynszu w wysokości 18 gr (co daje $14 \mathrm{fl} \mathrm{i} 12$ gr). Pozostałe daniny obejmowały po trzy korce żyta z półłanka (razem 72 po 22 gr), trzy korce owsa (po 11 gr), po jednym kapłonie (razem 24 po 2 gr)

${ }^{15}$ Polska XVI wieku pod względem geograficzno-statystycznym, wyd. A. Pawiński, Wielkopolska, t. 2, [w:] Źródła dziejowe, t. 13, Warszawa 1883, s. 88.

16 AGAD, MK 161, k. 225v-226.

${ }^{17}$ AGAD, MK 161, k. 104-104v. 
i 15 jajach (po 6 gr za kopę). Kmiecie zobowiązani byli do świadczenia pańszczyzny. Robocizna sprzężajna wynosiła dwa dni, a piesza jeden dzień z półłanka na tydzień. Jeden łan zwolniony był przy tym ze świadczeń, „z którego służbę wojenną wybraniec służyć powinien". We wsi w badanym okresie można również zidentyfikować nadziały zagrodnicze. Wykazano wówczas dziewięciu zagrodników, płacących czynszu po 6 gr każdy, a ponadto czterech karczmarzy, uiszczających czynsz w wysokości 24 gr. Zagrodnicy zobowiązani byli do dwóch dni pracy w zimie i trzech dni w lecie w trakcie żniw, a karczmarze do jednego dnia pańszczyzny sprzężajnej. Wszyscy osadnicy mieli także obowiązek świadczenia straży nocnej we dworze. W granicach wsi zlokalizowane były dwa stawy, jeden przy dworze, drugi w polu nad rzeką, przy czym ostatni z nich był nieużytkowany. W sąsiedztwie wsi funkcjonowało założenie folwarczne. Nastawione ono było na produkcję roślinną. Według lustratorów bowiem „bydła KJM w tym folwarku jako w dobrach sumą przedtym starą onerowanych nie bywało". Istnieje możliwość źródłowego określenia struktury zasiewów. Lustracja wskazuje na 202 korce żyta, 19 i 1/4 korca pszenicy, 46 korców jęczmienia, 201 korców owsa, 12,5 korca grochu. Wieś Wiączyń Polny obejmowała w okresie analizowanej lustracji 10,5 łanu, z czego 8,5 łanu było osiadłych i dwa puste. Osiadłe łany zamieszkiwało 17 kmieci, posiadających gospodarstwa półłanowe. Czynsz płacony w dniu św. Marcina był identyczny jak w Wiączyniu Leśnym i wynosił 18 gr (co daje 12 fl i 18 gr). Renta feudalna w naturaliach obejmowała po trzy korce żyta z półłanka (razem 63 po 22 gr), trzy korce owsa (po 11 gr), po jednym kapłonie (razem 21 po 2 gr) oraz 15 jaj (po 6 gr za kopę). Co ciekawe, zakładano rekompensatę ze strony dzierżawcy braków wynikających z tytułu pustych łanów, ,póki ich nie osadzi, które najdalej lat piąci osadzić winien". Kmiecie zobowiązani byli do świadczenia robocizny sprzężajnej i pieszej analogicznie jak w Wiączyniu Leśnym. Oprócz nadziałów kmiecych w lustracji wykazano istnienie gruntów czterech zagrodników i trzech karczmarzy, uiszczających czynsz i pańszczyznę w identycznej wysokości co w sąsiednim Wiączyniu. Zgodnie $\mathrm{z}$ danymi lustracyjnymi w centralnej części wsi istniał niewielki staw. Ogólny dochód wynikający z obu wsi i folwarku wynosił 429 fl 10 gr i 10 den (z czego na Wiączyń Leśny przypadało 101 fl 12 gr, na Wiączyń Polny 93 fl 7 gr i 9 den, na folwark zaś 250 fl i 21 gr oraz myto roczne w wysokości $16 \mathrm{fl})^{18}$.

${ }^{18}$ AGAD, ASK XLVI, 104, f. 426-428; Lustracja województw wielkopolskich i kujawskich 1616-1620, cz. 1, wyd. Z. Górski, R. Kabaciński, J. Pakulski, Wrocław 1994, s. $373-375$. 
Istotny materiał źródłowy na temat zagospodarowania tenuty wiączyńskiej dostarcza lustracja, wykonana kilkanaście lat później, w latach 1628-1632. Posesorem wsi pozostawał w tym czasie nadal podczaszy lubelski Paweł Lasocki. Zmieniło się jednak zasiedlenie badanych osad. W obrębie Wiączynia Leśnego wykazano 12 łanów ziemi, przy czym gospodarowało na nich tylko sześciu kmieci półłanowych. Mimo że część łanów bezkmiecych została zagospodarowana na rzecz folwarku, to dostrzec można pogłębiającą się tendencję rozwoju pustek osadniczych. Obciążenia feudalne w stosunku do poprzednio wykonanej lustracji pozostały na takim samym lub bardzo zbliżonym poziomie. Świadczenia nadal obejmowały czynsz, naturalia i robociznę. Kmiecie byli zobowiązani do zapłaty 18 gr, co daje, po dodaniu łanów opuszczonych czasowo przejętych przez dzierżawcę, $14 \mathrm{fl} \mathrm{i} 12$ gr. Renta naturalna uwzględniała daninę w postaci: trzech korców żyta z półłanka (72 po 26 gr), trzech korców owsa (72 korce po 20 gr), kapłona i 15 jaj. Pańszczyzna nadal obejmowała dwa dni sprzężajne i jeden dzień odrabiany pieszo (przy dwudniowej uldze z tytułu powozu). We wsi nadziały posiadało także trzech zagrodników i trzech karczmarzy (z czynszem odpowiednio 6 gr i 24 gr). Pańszczyzna zagrodników pozostała niezmienna, podobnie jak powinność w postaci straży. W strukturze społeczno-agrarnej Wiączynia Leśnego swoje miejsce zajmowali także inni rzemieślnicy, w tym dwaj kołodzieje, zobowiązani do przekazania rocznie na rzecz dworu jednego wozu. Poddani ,podług dawnego zwyczaju” zobligowani byli ponadto do świadczenia stacyjnego $\mathrm{w}$ formie czynszowej i naturaliów. W Wiączyniu Polnym, podobnie jak w analizowanej do tej pory wsi, doszło do uszczuplenia stanu liczebnego łanów osiadłych. W okresie lustracji zarejestrowano tylko ośmiu chłopów półłanowych przypadających na 10,5 łanu ogółem, a ponadto trzech zagrodników i dwóch karczmarzy. Świadczenia feudalne pozostały niezmienne w stosunku do poprzedniej lustracji, według stawek analogicznych do tych w Wiączyniu Leśnym. Można przypuszczać, że zmniejszenie stanu liczebnego osadników może mieć bezpośredni związek z klęską elementarną w postaci epidemii. Świadczyć o tym może zapis w lustracji na temat rzemieślników w Wiączyniu Polnym, których ,żadnego w tej wsi nie masz, bo przez powietrze zniesieni”. Ogólny dochód badanego klucza majątkowego wynosił 622 fl i 14 gr (z czego na Wiączyń Leśny przypadło $140 \mathrm{fl}$ i 19 gr, na Wiączyń Polny $123 \mathrm{fl}$ i 21 gr, a na folwark 467 fl i 20 gr). Ziemie folwarczne obejmowały zagony usytuowane w obrębie trzech pól, zgodnie z systemem łanowym dostosowanym do trójpolówki. W analizowanej lustracji zachował się także bardzo ciekawy opis zabudowy dworskiej, ukazujący szczegółowo ówczesną fizjonomię i formy użytkowania. Dwór z murowaną piwnicą, jak wskazuje przeprowadzona rewizja, zbudowany został niedawno przez dzierżawcę. Wjeżdżając do rezydencji, mijało 
się dwuczęściowe wrota $\mathrm{z}$ furtą. $\mathrm{Z}$ centralnie położonej sieni wychodziły poszczególne pomieszczenia, w tym sala stołowa z pięcioma oknami, dwoma stołami i ławami. Prowadziła z niej jedna izba i mała sień, dalej pokój z dwoma oknami, stołem i ławami. Za nim znajdował się pokój dla pań z trzema oknami z alkierzem. Do izb prowadziły „drzwi na zawiasach żelaznych z hantabą i haczykiem”. W pokojach znajdowały się przeważnie ",piece chędogie kafli polewanych" zielonych lub białych. W pobliżu dworu znajdowała się stajnia, mogąca pomieścić 40 koni. Lustratorzy wskazali również na nowo wybudowany spichlerz z pięcioma sąsiekami, a ponadto dwie stodoły i ,tamże obory dokoła porządnie budowane przy gumnie". Nieco dalej usytuowane były obiekty produkcyjne. Na szczególną uwagę zasługuje budynek browaru oraz położona w sąsiedztwie „ozdownia” (staropolskie określenie suszarni słodu) ${ }^{19}$.

Następny, cenny zbiór danych źródłowych na temat Wiączynia zawiera lustracja dóbr monarszych wykonana po potopie szwedzkim, sporządzona dla województwa łęczyckiego na podstawie rękopisu w 1661 r. (ryc. 1). W trakcie wykonanej rewizji posesorem obu wsi był Piotr Pruszyński h. Rawicz ${ }^{20}$ wraz z małżonką Małgorzata Lasocką h. Dołęga, wdową po Pawle Bełdowskim, łowczym łęczyckim ${ }^{21}$. W świetle materiałów archiwalnych zawartych w Metryce Koronnej uzyskujemy informację, zgodnie z którą obie wsie wiączyńskie Pruszyński uzyskał 27 lutego 1655 r. drogą cesji dokonanej przez dotychczasowego dzierżawcę - Pawła Lasockiego, podczaszego lubelskiego ${ }^{22}$. Zniszczenia wojenne $\mathrm{i}$ ich dalsze reperkusje spowodowały poważne ubytki w zabudowie wsi oraz depopulację. Znamienna $\mathrm{w}$ treści jest $\mathrm{w}$ tym przypadku relacja angielskiego kupca J. Marshalla, który, podróżując wiosną 1670 r., pisał: „Z Rawy do Sieradza obszar ten jak można dostrzec, był kiedyś uprawny, teraz napotkaliśmy tu tylko trzy niezamieszkałe wsie. Pozostałe były doszczętnie spalone a mieszkańcy uciekli" (Zawadzki 1963, s. 324). Skutki pożogi wojennej dotknęły również badane wsie wiączyńskie. W Wiączyniu Leśnym wykazano ze względu na „spustoszenia przez różne calamitates publicas" (katastrofy) obecność tylko sześciu osiadłych poddanych, gospodarujących na kwarcie lub ćwierci łanu. W Wiączyniu Polnym zarejestrowano zaś tylko czterech kmieci półłanowych. Jak nietrudno dostrzec, spadkowi zasiedlenia towarzyszyło również wyraźne

${ }^{19}$ Lustracja województw wielkopolskich i kujawskich 1628-1632, cz. 3: województwa łęczyckie, brzesko-kujawskie, inowrocławskie i ziemia dobrzyńska, wyd. Z. Guldon, Bydgoszcz 1967, s. 32-35.

${ }^{20}$ Niesiecki K., Herbarz Polski, wyd. J. Bobrowicz, t. 10: Dodatek, Lipsk 1845, s. 361 .

${ }^{21}$ Boniecki, t. 13, s. 390.

${ }^{22}$ AGAD, MK, 195, k. 177v-179. 
rozdrobnienie gruntów chłopskich. W Wiączyniu Leśnym wykazano ponadto trzech zagrodników, w Wiączyniu Polnym ich obecności na podstawie analizowanej lustracji nie stwierdzono. W ówczesnej sytuacji zobowiązania feudalne wobec chłopów pozostały jednak niezmienne. W warunkach gwałtownego wyludnienia i wzrostu łanów opustoszałych dochód majątku uległ radykalnemu obniżeniu. W Wiączyniu Leśnym uzyskano razem tylko 18 korców żyta i owsa oraz sześć kapłonów, a w Wiączyniu Polnym po 12 korców żyta i owsa oraz cztery kapłony. Z uwzględnieniem ziemi folwarcznej uzyskano dochód w łącznej wysokości jedynie $284 \mathrm{fl} \mathrm{i} 17$ gr. Wyraźnemu obniżeniu uległa efektywność

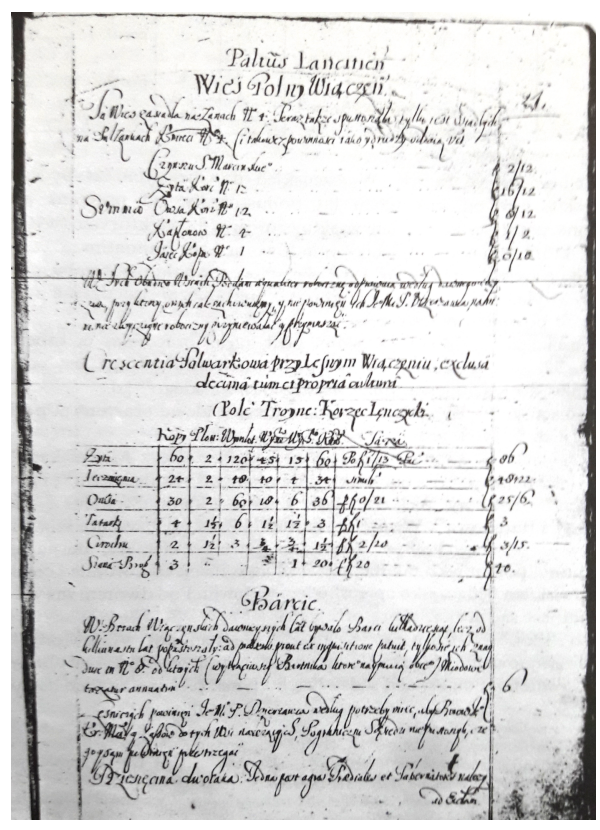

Ryc. 1. Fragment lustracji Wiączynia Polnego i Leśnego z lat 60. XVII w. Źródło: AGAD, ASK XLVI, 154, s. 21; LWWK 1665, s. 211 produkcji rolnej. Zarejestrowano w tym czasie 60 kop żyta, 24 kopy jęczmienia, 30 kop owsa, dwie kopy grochu i trzy kopy siana. Obszar wokół badanych wsi był w tym czasie gęsto zalesiony, stanowiąc element składowy Puszczy Łódzkiej. Z uwagi na to funkcjonowała tu ex antiquo gospodarka leśna związana $\mathrm{z}$ istnieniem barci. Według lustratorów w borach wiączyńskich bywało ich dawniej kilkadziesiąt, ale ze względu na sytuację polityczną $i$ jej konsekwencje pozostało ich tylko osiem, z których płacono podatek miodowy. W lasach dzierżawcy działali ponadto leśniczy, pilnujący, aby „lasów do tych wsi należących pograniczni sąsiedzi nie pustoszyli”. Warto dodać, że w analizowanym okresie karczmy wiączyńskie uległy zanikowi i ,żaden z nich pożytek ani usługa dworowi nie idzie". Podobnie rzecz się ma z gospodarką stawoworybną. Wskazano co prawda na istnienie stawu w Wiączyniu Polnym, ale okazał się on niezarybiony, po tym gdy ,nieprzyjaciel jako i wojsko koronne tak stanowiskiem będąc, jako i przychodem wyłowili”. Stwierdzono ponadto, że sadzawka w rejonie dworu w Wiączyniu Leśnym wyschła niemal zupełnie. Budynek dworski okazał się zrujnowany, natomiast stodoła i obory wymagały pilnych prac naprawczych ${ }^{23}$.

${ }^{23}$ AGAD, ASK XLVI, 154, s. 20-22; LWWK 1659-1665, s. 210-213. 


\section{Stan zagospodarowania i rozplanowania wsi w drugiej połowie XVIII wieku}

Wierny obraz stanu zagospodarowania przestrzennego obu sąsiadujących ze sobą wsi ze wspólnym członem toponimicznym Wiączyń odnajdujemy dopiero w okresie stanisławowskim, u schyłku istnienia I Rzeczypospolitej. Warto nadmienić, że poddane szczegółowej analizie osady Wiączyń Polny i Leśny występowały w tym czasie w źródłach równolegle pod różnymi nazwami, co już wcześniej sygnalizowano, omawiając zapiski z wczesnonowożytnych rejestrów poborowych. Dla przykładu w aktach sądowych Asesorii Koronnej z 1791 r., dotyczących procesu mieszczan brzezińskich z dziedzicami o pogwałcenie przywilejów miejskich, pojawiają się określenia Wiączyń Wielki, który należy kojarzyć z Dolnym lub Polnym, oraz Wiączyń Mały, utożsamiany z Leśnym lub Górnym (Tomczak 1957, s. 347). Niestety wyniki wizytacji parafii sporządzonych przez proboszczów w odpowiedzi na ankietę z $1782 \mathrm{r}$. nie zachowały się do naszych czasów. Dysponujemy jedynie wydanym w 2006 r. Regestrem diecezjów Franciszka Czaykowskiego..., który pozwala potwierdzić stan własnościowy osad. Istnieje natomiast możliwość wykorzystania informacji z rejestrów skarbowo-podatkowych oraz bogatego zasobu danych źródłowych, które można czerpać z lustracji królewszczyzn województwa łęczyckiego pochodzącej z czasów Sejmu Czteroletniego, tj. z 1789 r. Inwentaryzacja została wykonana 19 lipca przez lustratorów działających w zgodzie z zapisami prawa „Bezpieczeństwo podatku z dóbr królewskich” oraz „Sposób wynalezienia ofiary z dóbr ziemskich i duchownych w Koronie i w Wielkim Xięstwie Litewskim"24. Posesorami obu Wiaczyniów w tym czasie było małżeństwo Stanisława Radwana Zebrzydowskiego i Konstancji Czajkowskiej. Uzyskali oni prawo dożywotniej dzierżawy klucza wiączyńskiego na podstawie decyzji króla Augusta III z 17 sierpnia 1760 r. po zrzeczeniu się swej jurysdykcji przez Katarzynę z Rychłowskich Czajkowskiej, co zostało potwierdzone w aktach Trybunału Koronnego w Piotrkowie i oblatowane w księgach ziemskich powiatu brzezińskiego ${ }^{25}$. Lustracja zawiera skomasowane dane dotyczące obu Wiączyniów za trzy lata łącznie, dotyczące wysiewów zbóż i zbiorów siana, czynszów, danin i dochodów z tytułu wyszynku. W ten sposób możliwe jest m.in. dokonanie rekonstrukcji struktury zasiewów. I tak trzyletni wysiew żyta wynosił 80 korców po 5 zł każdy (na rok

${ }^{24}$ Volumina legum, t. 9, Kraków 1889, s. 77, 100.

${ }^{25}$ Lustracja województw wielkopolskich i kujawskich 1789 (dalej LWWK 1789), cz. 3: Województwa łęczyckie i brzesko-kujawskie, wyd. A. Tomczak, Z. Kędzierska, Warszawa-Poznań-Toruń 1977, s. 181. 
26 korców, dwie ćwierci i sześć garnców), żyta jarego 38 korców po 4 zł (średnio 12 korców na rok), pszenicy jarej dziesięć korców (trzy korce i dwie ćwierci na rok) po 7 zł według taksy komisji powiatowej, jęczmienia 45 korców po 3 zł (15 korców na rok), owsa 122 korce i jedną ćwierć (przeciętnie 40 korców i trzy ćwierci rocznie) po 2 zł, grochu trzy korce (po jeden na rok) po 5 zł każdy, prosa jeden korzec i dwie ćwierci (po dwie ćwierci rocznie) po 7 zł. Na miejscu prowadzony był wyszynk własnej gorzałki dworskiej, który wynosił 453 garnce (151 rocznie), piwa zaś odpowiednio 105 stągwi i 33 garnce (rocznie 35 stągwi i 11 garnców). Posesor w trakcie lustracji uskarżał się jednak na gromadę, „iż ci po cudzych piją karczmach”. Od każdego zagrodnika należna była danina w postaci czterech sztuk kapłonów, jednej kury i 15 jaj, w tym $\mathrm{z}$ odnotowanych $\mathrm{w}$ okresie lustracji trzech łanów pustych, które posesor obsiewał, albowiem z tych „ról tak jako z inszych czynsze i daniny ustanawiają się do prowentu". Półrolnicy przekazywali pięć kapłonów, jedną kurę, dwie gęsi i 15 jaj. Zagrodnicy byli zobligowani do dwóch lub trzech dni robocizny i podatku łanowego w wysokości 6 zł 15 gr lub 7 zł 15 gr. Półrolnicy zaś odrabiali pańszczyznę czterodniową i płacili 8 zł łanowego. Roczny dochód majątku szacowany był na 869 zł i 27 gr, co przy uwzględnieniu 70 zł dziesięciny z gruntów folwarcznych na rzecz kościoła w Mileszkach dało „prowent roczny” w wysokości 399 zł i 28 gr płacony przez dzierżawcę (dla porównania do skarbu w 1765 r. trafiło 355 zł i 17 gr, poddani zaś zobowiązani byli do zapłaty 100 zł podatku łanowego, co z kolei pozostało niezmienne).

Niewątpliwie ważnym elementem zagospodarowania przestrzennego Wiączynia i okolic były duże kompleksy leśne. Na ich wartość użytkową szczególną uwagę zwrócili także lustratorzy. Warto dodać, że część lasu wiączyńskiego w okresie poprzedzającym lustrację podlegała wypalaniu, w obrębie boru wykupionego przez prymasa Antoniego Ostrowskiego (a zatem między 1777 a 1784 r.). W wyniku objazdu terenowego lustratorzy określili w sposób ogólny skład gatunkowy puszczy otaczającej Wiączyń. Stwierdzili obecność świerczyny, jedliny, brzeziny z dodatkiem osiczyny, leszczyny, a ponadto zwrócili uwagę na sośninę „bardzo wysokości, prostości i gładkości pięknej, grubą i cienką, do wszelkiej budowli zdatną". Dębina, zdaniem lustratorów, była jeszcze zbyt młoda do wykorzystania gospodarczego, a często również wyschnięta, dlatego posesorowi nakazali, by jej „obdzierać ze skór zabronieł i pustoszenia lasów przestrzegał, jako i gromadzie przykazał, aby tego obdzierania dębiny więcej czynić nie ważyła się". W tym kontekście posesor skarżył się lustratorom, że członkowie gromady odzierają dębinę i wywożą pozyskany surowiec do Strykowa, gdzie sprzedają go miejscowym szewcom. Gromada natomiast w kontrze stwier- 
dziła, że dębinę nie mieszkańcy Wiączynia Leśnego, lecz poddani „z innych wsiów z skór odzierają" 26 .

Lustracja z 1789 r. jest bogata w szczegółowy opis zabudowy obu Wiączyniów, zarówno obiektów dworsko-folwarcznych, jak i chłopskich. Zacznijmy analizę od zabudowań posesjonata. Najważniejszy w tym zakresie pozostaje dwór. Wjeżdżając ze wsi na dziedziniec „całemi świerkami oparkaniony”, należało przebyć drewniane wrota $\mathrm{z}$ furtką, nad którą znajdował się niewielki daszek. We frontalnej części dworu usytuowany był nowy ganek, a dach obity był gontem. Z centralnie położonej sieni, gdzie znajdowała się kuchnia „Z gliny połową z pruska lepiona", przechodziło się do poszczególnych pomieszczeń. Po prawej stronie zlokalizowany był pokój z trzema oknami oraz ceglanym piecem, za nim mniejszy i niewykończony pokój oraz garderoba. Po lewej stronie od sieni znajdowały się pomieszczenia gospodarcze w złym stanie technicznym, w których przebywali czeladnicy. Po lewo od dworu, w kierunku wrót na pole, usytuowane były budynki folwarczne w postaci starej i poszytej snopkami obory oraz nowej, dużej stodoły z drzewa kostkowego, o dwóch klepiskach. Nieco dalej stał spichlerz wraz z lamusem, pod którym znajdowała się piwnica. Obok lamusa zlokalizowana była stajnia i wozownia pod jednym dachem pokrytym dranicami. W szczycie stajni odnotowano cztery chlewy, a w szczycie dworu trzy kurniki. Po lewej stronie od dworu, przy drodze prowadzącej ku wsi, usytuowany był budynek browaru z kostkowego drzewa, z izbą i komorą po jednej stronie sieni i gorzelnią po drugiej. Tuż obok postawiona była niewielka, stara suszarnia słodu.

Dalej odnajdujemy inwentarz zabudowań chłopskich na terenie Wiączynia Polnego. Odnotowano w tym przypadku osiem chałup mieszkalnych, niekiedy wraz otoczeniem gospodarczym. Z nazwiska wymienieni są półrolnicy: Tomasz Gabara z synem oraz Jędrzej Sołdon, posiadający drewniane chałupy z drewna kostkowego i obory. Oprócz nich uwzględnionych zostało kilku zagrodników (w porządku przestrzennym lokalizacji zagród: Wincenty, Adam Gabara, Maciej, Józef Żurek, Jan i Kacper - nazwiska nieznane). Kolejno wskazano chałupę zamieszkaną przez komorników oraz kuźnię. Posesor klucza wiączyńskiego uskarżał się podczas lustracji, że członkowie gromady „,chałup dla siebie stawiać nie chcą, tylko budować im musi”. Analogiczny opis zabudowy chłopskiej znajduje się w rejestrze dotyczącym Wiączynia Leśnego, w którym odnotowano również osiem chałup. Pierwszą chałupę zamieszkiwał półrolnik Mateusz Zasada. Kolejno chałupy posiadali zagrodnicy: Wawrzyniec Doruszka, Jakub Basa,

${ }^{26}$ AGAD, ASK XLVI, 173, s. 251-257; LWWK 1789, s. 181-184. 
Karol Piejak, Walenty Gabara, Józef Przybył i Augustyn Kupiński. Chałupy były dwuizbowe, a towarzyszyły im zazwyczaj stodoły i obory o zróżnicowanym stanie technicznym. $Z$ nazwiska wymieniony został ponadto komornik Walenty Grzanecki, posiadający niewielką chałupę i oborę w centrum wsi. Na samym końcu wsi znajdowała się karczma, zlokalizowana przy trakcie do Warszawy i Widawy (zgodnie $\mathrm{z}$ treścią lustracji), obejmująca zaniedbany gościniec i stajnię ${ }^{27}$.

Wiedzę na temat zagospodarowania przestrzennego wsi, odtworzonego na podstawie lustracji królewszczyzn z 1789 r., uzupełnia analiza wielkoskalowych źródeł kartograficznych. Szczególne znaczenie poznawcze wykazują w tym zakresie plany opracowane w 1796 r. przez Zillego na zlecenie władz pruskich. W pierwszej kolejności przyjrzyjmy się bliżej układowi przestrzennemu Wiączynia Polnego (ryc. 2$)^{28}$.

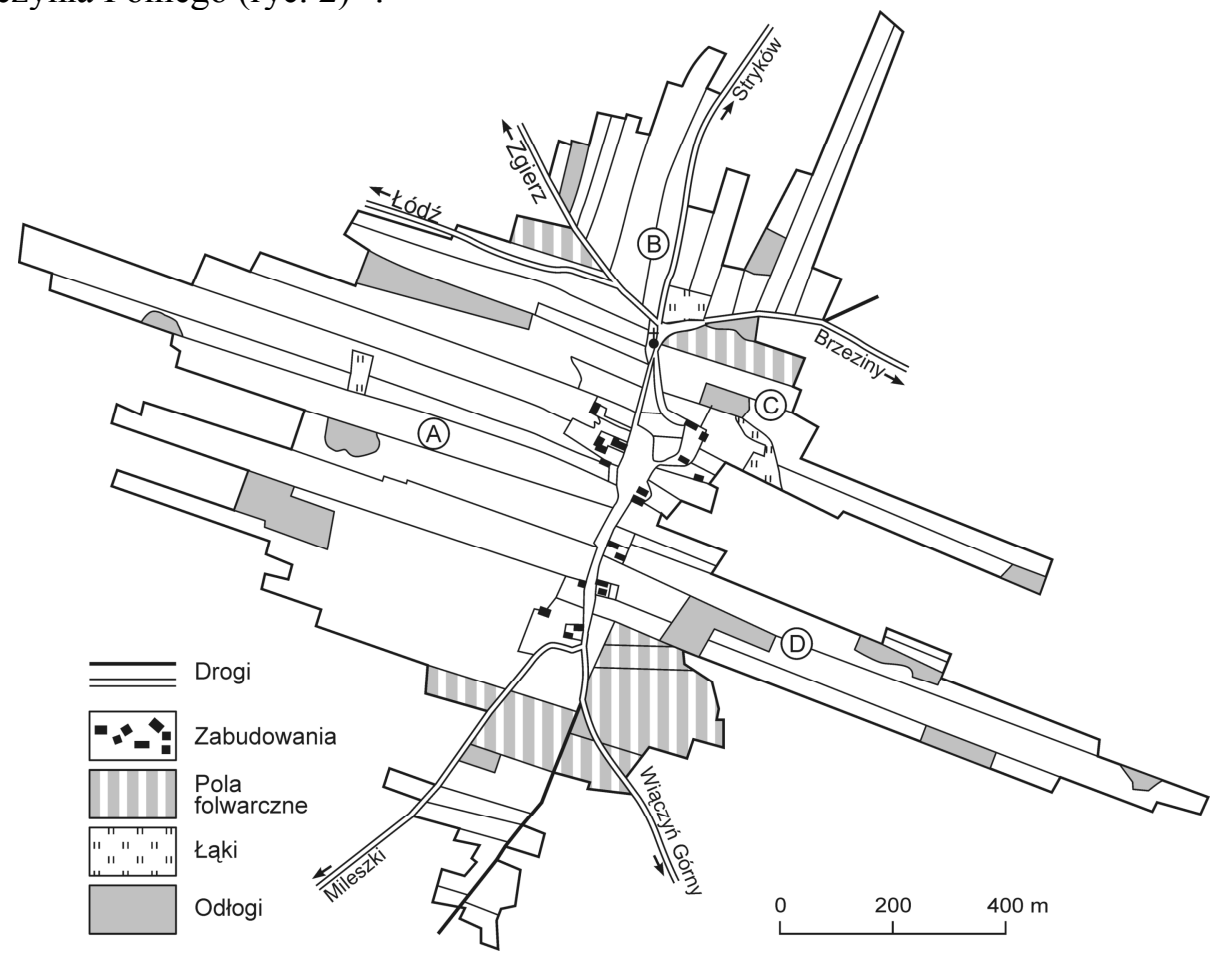

Ryc. 2. Układ przestrzenny Wiączynia Polnego w 1796 r. Źródło: odrys na podstawie AGAD, Zbiór kartograficzny, 326-17; P. Kotkowski (1991, mapa 18)

${ }^{27}$ AGAD, ASK XLVI, 173, s. 268-274; LWWK 1789, 188-192.

${ }^{28}$ AGAD, Zbiór kartograficzny, sygn. 326-17: II Spezial Karte von den Laendereyen der Koenig Starostey Nieder Wionczyn, Zille, 1:5000, 1796. 
Jego granice miały wyjątkowo zmienny przebieg, a obszar wsi nie wykazywał zwartego charakteru, co było efektem ewolucyjnego rozwoju, wynikającego z sukcesywnie realizowanego karczunku. Siedlisko wiejskie miało formę nieregularnej wsi placowo-ulicowej. Zagrody, wymienione w wykonanej kilka lat wcześniej lustracji, usytuowane były wzdłuż południkowej, krzywoliniowej drogi. Były to gospodarstwa należące do półłanowych kmieci i poszczególnych zagrodników. W części północnej droga ulegała rozszerzeniu w postaci niewielkiego placu, przy którym mieszkali pozostali chłopi, w tym chałupnicy. Można również przypuszczać, że w tym miejscu była zlokalizowana kuźnia. Rozłogi podzielone były na pięć nieregularnych pól. Zagony wchodzące w ich skład były nierównej wielkości i tworzyły na ogół pasma różnej długości. Nadziały gruntów miały układ równoleżnikowy, prostopadły do drogi, z wyjątkiem pola w północnej części wsi, gdzie zagony przebiegały południkowo. Jedno z pól, zlokalizowane południowo-wschodniej części wsi, tworzyło strukturę blokową, należącą do folwarku. Droga wiejska w części północnej, za kapliczką, ulegała rozwidleniu na cztery odnogi, prowadzące do Łodzi, Zgierza, Strykowa i Brzezin. Na południu droga dzieliła się na trzy ramiona, w kierunku Mileszek i Wiączynia Górnego.

Układ przestrzenny Wiączynia Leśnego w świetle zachowanego planu archiwalnego można określić mianem wsi wielodrogowej (ryc. 3) ${ }^{29}$. Rozwijała się ona ewolucyjnie i z tego względu wykazywała nieregularny charakter. Poszczególne zagrody nie tworzyły zwartej struktury, lecz były usytuowane luźno w centrum układu, wzdłuż głównej drogi o przebiegu zbliżonym do równoleżnikowego oraz odchodzących od niej dróg bocznych. Znamienne jest jednak, że działki siedliskowe dość wyraźnie oddzielone były od rozłogów i tworzyły nieregularną niwę domową. We wschodniej części wsi, na zwieńczeniu osi kompozycyjnej, zlokalizowano założenie folwarczne. Tworzył go dwór usytuowany w sąsiedztwie stawu i liczne zabudowania gospodarczo-magazynowe (np. stodoła, spichrz, wozownia, stajnia, chlew, obora). Po drugiej stronie drogi był zakład produkcyjny w postaci gorzelni i browaru.

${ }^{29}$ AGAD, Zbiór kartograficzny, sygn. 326-74: Situations-Plan von der Hofflage und Vorwerks Gebauden der Koenigs Starostey Ober Wionczyn, Zille, 1:5000, 1796; sygn. 326-14: I Spezial Karte von Saemtlichen zu den Starostey Ober-Wionczyn gehoerige Herrschafts und Unteranen Laendereyen, Zille, 1:5000, 1796. 


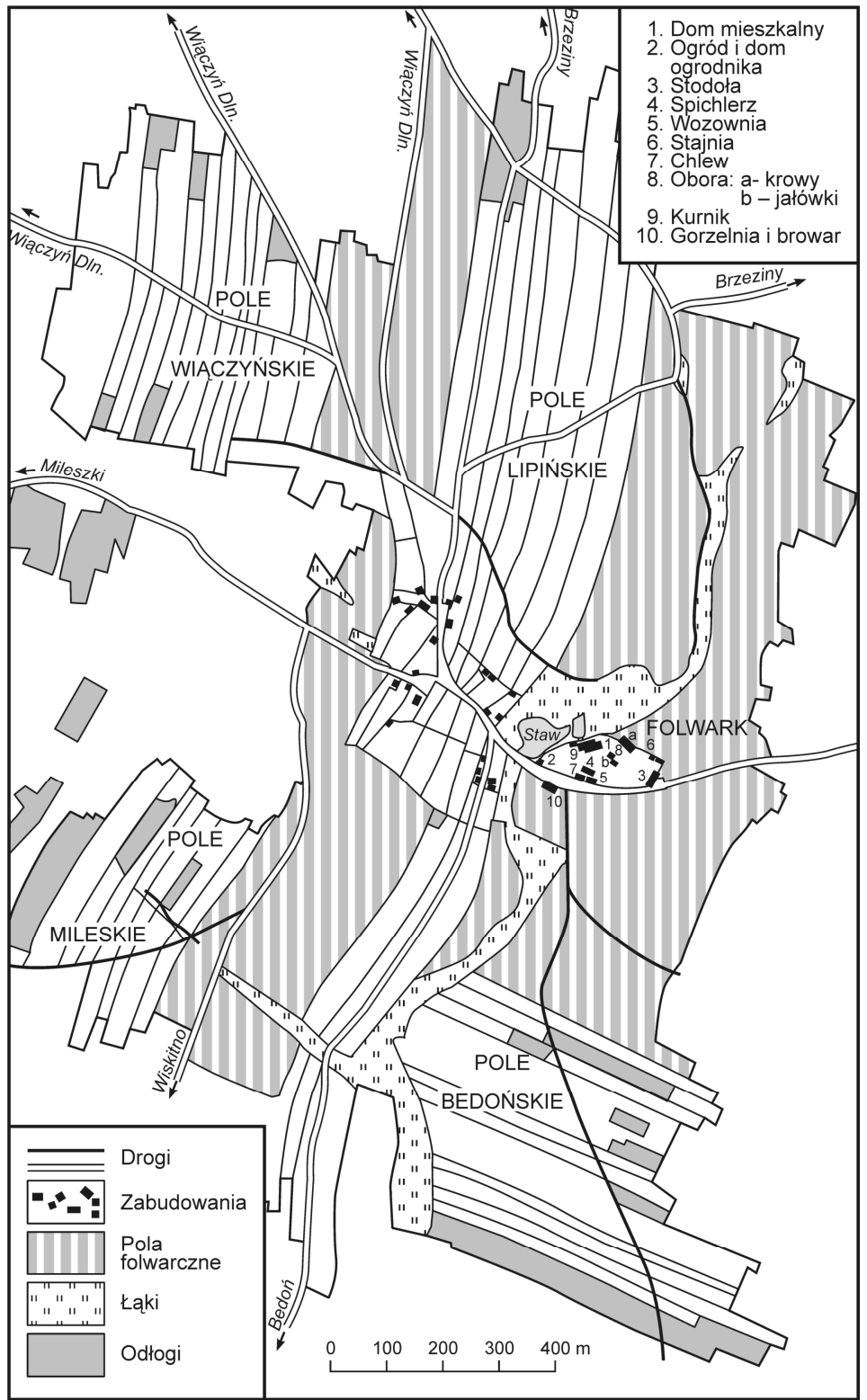

Ryc. 3. Układ przestrzenny Wiączynia Leśnego w 1796 r.

Źródło: odrys na podstawie AGAD, Zbiór kartograficzny, sygn. 326-14, sygn. 326-74; P. Kotkowski (1991, mapa 19)

Rozłogi wiejskie miały charakter szachownicowy w formie wielu nieregularnych niw. Składały się one z zagonów pasmowym o zbliżonym przebiegu i tworzyły razem: Pole Wiączyńskie, Lipińskie, Mileskie i Bedońskie (od nazw 
sąsiadujących wsi). Warto dodać, że rozłogi folwarczne były zblokowane i stanowiły zwarte komponenty morfologiczne, obecne w obrębie każdej z wydzielonych niw.

\section{Zanik Wiączynia i sukcesja osadnicza związana z powstaniem kolonii pruskich na przełomie XVIII i XIX wieku}

Schyłek XVIII w. przyniósł radykalną zmianę stosunków osadniczych na badanym obszarze. Zaledwie kilkanaście lat od momentu wykonania ostatniej lustracji dóbr monarszych obie wsie Wiączyń przestały istnieć w swym dotychczasowym kształcie, biorąc pod uwagę ich układ przestrzenny, strukturę prawno-gospodarczą oraz skład narodowościowo-religijny. W 1793 r. doszło do podpisania traktatu rozbiorowego między Katarzyną II a Fryderykiem Wilhelmem II. Na jego mocy Prusom przypadł Gdańsk i Toruń oraz ziemia dobrzyńska i województwa gnieźnieńskie, poznańskie, łęczyckie, sieradzkie, kaliskie, płockie, brzeskokujawskie, inowrocławskie oraz części rawskiego i mazowieckiego (o łącznej powierzchni 57 tys. $\mathrm{km}^{2}$ ). Inkorporowany obszar stanowił podstawę do utworzenia nowej prowincji Prus Południowych, w obrębie której natychmiast wprowadzono nowy system prawno-administracyjny. W efekcie diametralnej zmiany granic postanowiono kontynuować akcję kolonizacyjną, zainicjowaną wcześniej przez króla Fryderyka II. Miała ona na celu wykorzystanie gospodarcze nieużytkowanych dotąd terenów i odegrała kluczową rolę w procesie germanizacji nowo podbitych terenów dawnej Rzeczypospolitej (Zimmermann 1915, Wąsicki 1957). Niewątpliwie duże znaczenie w rozwoju sieci osadniczej miały przejęte przez władze pruskie na własność dawne królewszczyzny oraz poddane sekularyzacji rozległe dobra kościelne (Figlus 2014b). Po objęciu rządów przez Fryderyka Wilhelma III, w wyniku aktywności ministra Otto von Vossa zorganizowano aparat rekrutujący potencjalnych osadników, w głównej mierze $\mathrm{z}$ terenu Badenii i Wirtembergii, ze względu na panujące tam przeludnienie i problemy gospodarcze (Woźniak 2013, s. 78-82). W ten sposób przedstawiają się okoliczności reaktywacji kolonizacji fryderycjańskiej na badanym obszarze, które ostatecznie doprowadziły do całkowitego zaniku obu Wiączyniów i powstania na ich miejscu nowych struktur osadniczych. Jest to oczywiście znaczne uproszczenie i zgeneralizowany obraz zachodzących wówczas procesów, pomijający wiele mniej istotnych szczegółów historycznych natury prawno-administracyjnej (szerzej: Woźniak 2015). Warto podkreślić, że zgodnie z przyjętymi regulacjami, osadnicy otrzymywali grunty na zasadach dzierżawy wieczystej i zobowiązani byli do uiszczania czynszu po upływie kilkuletniej wolnizny. 
Na terenie obu Wiączyniów, jako dawnych wsi królewskich, w krótkim czasie doszło powstania nowych jednostek osadniczych. Na obszarze dawnego Wiączynia Polnego rozwinął się układ Neu-Sulzfeld, natomiast na miejscu Wiączynia Leśnego powstały wsie: Niederwiontschin, Oberwiontschin, Neuwiontschin. Dopiero w czasach tzw. królestwa kongresowego uzyskały one formalnie nazwy polskie: Nowosolna, Wiączyń Dolny, Wiączyń Górny i Wiączyń Nowy. Pierwsza $\mathrm{z}$ wymienionych nazw nawiązywała do miejsca pochodzenia większości pierwszych osadników, tj. miejscowości Sulzfeld, znajdującej się w północnej Badenii, na południe od Eppingen, między Stuttgartem a Heidelbergiem. Kolejne nazwy nowo założonych osad stanowiły zniemczone formy wcześniej istniejącej wsi polskiej. Rozwój Neu-Sulzfeld, jako największej z powstałych wsi pruskich, w głównej mierze możliwy był dzięki dużej aktywności faktycznego zasadźcy Bernharda Zimmermanna. Jeszcze w 1800 r. dokonał on wstępnego rozeznania warunków zasiedlenia w Prusach Południowych. Po drodze uzyskał w Berlinie obietnice dotyczące praw przysługujących jemu i zwerbowanym osadnikom, po czym powrócił do rodzinnego Sulzfeld. Wiosną $1801 \mathrm{r}$. Zimmermann wyruszył na wschód wraz z pierwszą grupą migrantów. Po interwencji u króla uzyskał zgodę na zwerbowanie kolejnej grupy małorolnych osadników, którym odmówiono wcześniej nadania dużych gospodarstw w kamerze warszawskiej, proponując małe nadziały w kamerze kaliskiej. Tym sposobem zorganizowano grupę 60 rodzin (głównie z Sulzfeld, Heilbronn, Isfeld oraz Schoenbronn) gotowych do zasiedlenia w przydzielonym rejonie dawnych wsi królewskich Wiączyń (Schöler 2009, s. 24, Woźniak 2015, s. 109-110).

W trakcie planowania nowych kolonii napotkano jednak na problem zbyt małej powierzchni wolnej do zagospodarowania, odpowiedniej na potrzeby tak dużej liczby osadników. Podczas rozmierzania wsi podjęto zatem decyzję o przesiedleniu autochtonicznej ludności polskiej, zamieszkującej do tej pory Wiączyń Polny i Leśny. Kosztem rządu pruskiego postanowiono wykarczować fragment lasu i utworzyć kolonię Wiączyń Nowy, do której translokowano 15 polskich chłopów pańszczyźnianych, którzy zostali oczynszowani (Kossmann 1942, s. 112, Heike 1979, s. 88). Likwidacja dotychczasowej zabudowy i usunięcie dotychczasowych mieszkańców stanowi definitywny moment zaniku funkcjonowania Wiączynia Polnego i Leśnego oraz rozwój nowych wsi pruskich. Zimmermann jeszcze w 1801 r. postanowił wybrać się do rodzinnego Sulzfeld, aby zabrać resztę majątku. Podczas postoju w Poczdamie, za namową komisarza Nothardta, zwerbował jeszcze ok. 50 rodzin celem zasiedlenia w domenie Łaznów (Kossmann 1942, s. 130). Nowa fala kolonizacyjna sprawiła, że z czasem w Nowosolnej zaczęło brakować miejsc dla nowych osadników. Wirtemberczyków zaczęto osiedlać zatem w nowo rozmierzonym Wiączyniu 
(Dolnym i Górnym), ale także w Augustowie (Friedriechshagen) i Łaznowskiej Woli (Grömbach) (Heike 1979, s. 99-100). Większość osadników uzyskało na własność nadziały 2-4 łanowe. Dzięki specjalnemu wsparciu mogli samodzielnie budować domy, natomiast gospodarzom posiadającym 30 morgów i chałupnikom budynki wznoszono na koszt rządu. W 1806 r. na terenie dawnego Wiączynia rozmierzono 212 łany i pięć morgów ziemi. Odnotowano w tym czasie 115 zagród, zamieszkiwanych łącznie przez 510 osób (Schiewe 2000, Aneks) ${ }^{30}$. W strukturze użytkowania ziemi lasy obejmowały 5499 morgów, ziemie pod uprawę żyta i owsa odpowiednio 631 morgów, łąki średniej i złej jakości 46 morgów, tereny pokryte zaroślami zajmowały 50 morgów, nieużytki zaś 146 morgów (Heike 1979, s. 66).

Jak wcześniej wspomniano, na miejscu zlikwidowanej wsi Wiączyń Polny zaprojektowano nową, regularną kolonię o nazwie Neu-Sulzfeld (Nowosolna). Jej układ ruralistyczny wykazywał się znaczną oryginalnością. Nietypowość polegała na zastosowaniu formy promienisto-koncentrycznej (ryc. 4) Zastosowanie takiego modelu organizacji przestrzennej stanowiło prawdopodobnie efekt nawiązania do miasta Karlsruhe, położonego na terenie południowo-zachodnich Niemiec, skąd w większości wywodzili się osadnicy (Kokotkiewicz 1984/1985). Warto nadmienić, że w Polsce podobny układ przestrzenny mają także miejscowości Kup i Pokój na Śląsku Opolskim, powstałe także w ramach kolonizacji fryderycjańskiej. Według M. Kotera (1994, s. 84) zastosowany sposób rozplanowania był zdeterminowany chęcią odzwierciedlenia wcześniejszego układu wielodrożnego Wiączynia, na gruntach którego utworzono kolonię. Można przypuszczać, że dawny schemat dróg lokalnych mógł stanowić inspirację do budowy osady przez mierniczych (np. Sieverta i Kramma) według podobieństwa do form inicjalnych. Sporządzony w 1802 r. przez Künzela plan Nowosolnej ukazuje jej pierwotny układ przestrzenny ${ }^{31}$. Jego kształt można określić mianem gwiaździstego (Chilczuk 1970, s. 403). Rozłogi wiejskie z uwagi na unikatowe rozplanowanie przyjęły kształt trapezoidalny. Zagrody były rozmieszczone w regularnych odstępach po obu stronach ośmiu prostoliniowych dróg. Dodatkowo rozmierzono osiem promieni pomocniczych służących podziałowi pól. W centrum układu usytuowany był plac, przy którym wydzielono grunty użytkowane na rzecz całej gromady, związane z funkcjami społeczno-kulturowymi i religijnymi. W Nowosolnej na złączeniu dróg Künzel wyznaczył niewielkie działki

${ }^{30} \mathrm{Na}$ podstawie: Generaltableau über den Fortgang des Kolonistenwesens in Südpreußen, 13.02.1806; por. AGAD, Generalne Dyrektorium Departamentu Prus Południowych, sygn. 1008 .

${ }^{31}$ Biblioteka Uniwersytetu Warszawskiego, Gabinet rycin, GR 300, sygn. 299. 
przeznaczone dla rzemieślników i budynki użyteczności publicznej. W środku zostawiono miejsce na kościół i cmentarz. W osadzie powstały także: szkoła, karczma, kuźnia i wspólna studnia. W Nowosolnej pierwszy, drewniany budynek szkoły wystawiono w 1803 r., w 1805 r. oddano zaś do użytku kościół dla ewangelików. Warto dodać, że wśród mieszkańców Nowosolnej ważną rolę odgrywali również herrnhuci (bracia morawscy), dla których wieś stała się w niedługim czasie centrum życia religijnego (Hochgeladen 1937).

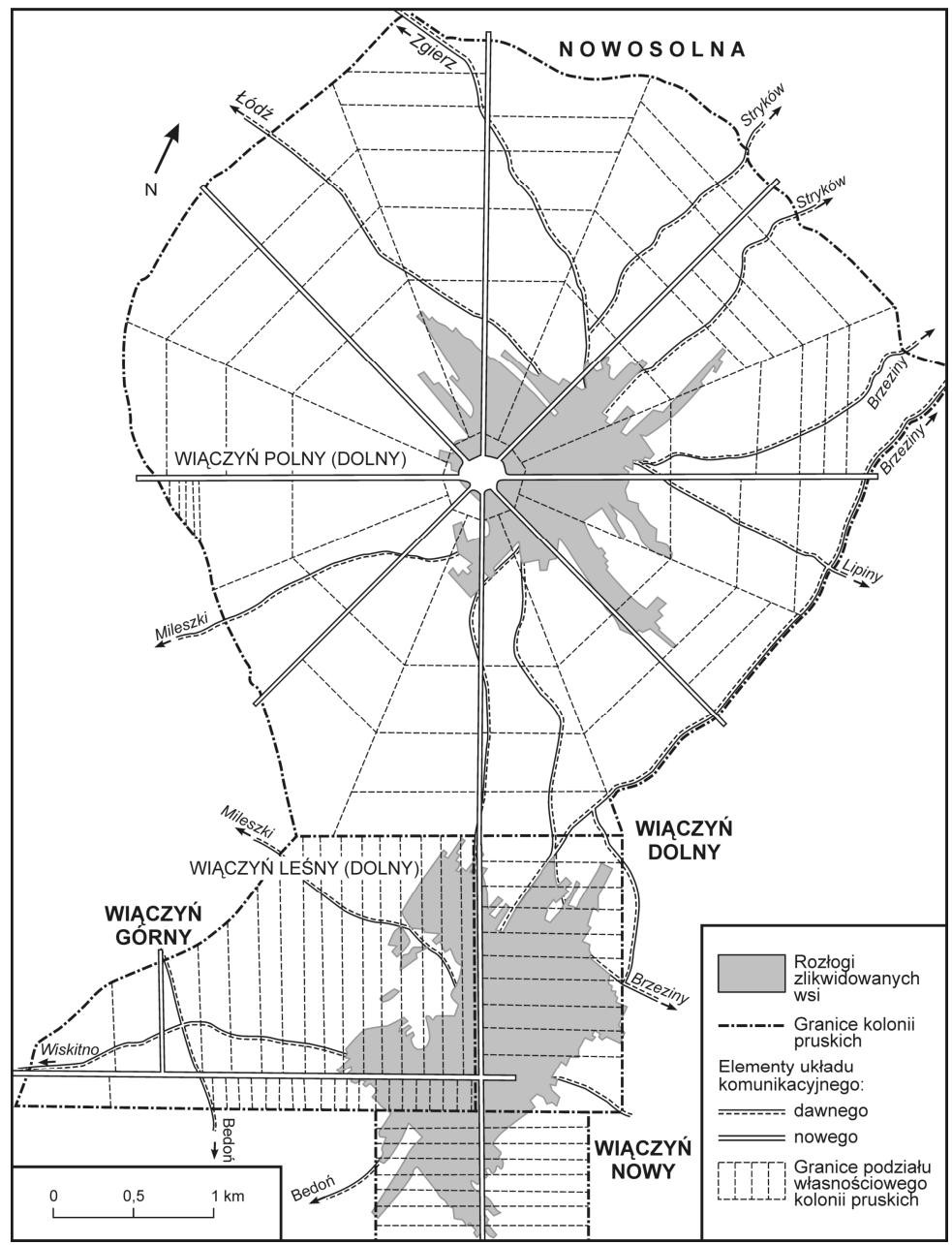

Ryc. 4. Układ przestrzenny nowych koloni pruskich w 1803 r. (Nowosolnej, Wiączynia Górnego, Dolnego i Nowego) na tle wcześniejszych struktur osadniczych (Wiączynia Polnego i Leśnego) Źródło: odrys na podstawie AGAD, Zbiór kartograficzny, sygn. 287-15, sygn. 327-1; P. Kotkowski (1991, mapa 20) 
Na gruntach rozparcelowanej wsi Wiączyń Leśny rozwinęły się wtórnie na początku XIX w. układy ruralistyczne w postaci rzędówek (ryc. 4), formy rozpowszechnionej $\mathrm{w}$ grupie wsi fryderycjańskich, stosowanej równie często w procesie rozmierzania osad olęderskich (Figlus 2014a). Wytyczony najwcześniej Wiączyń Górny cechował się dwustronną, naprzemianległą zabudową, usytuowaną wzdłuż prostoliniowej drogi, biegnącej z południowego zachodu na północny wschód. W inicjalnej fazie Wiączyń Górny obejmował 37 siedlisk. W pierwszej połowie XIX w. Wiączyń Górny powiększono o 12 siedlisk. Nieco później, wraz z postępem akcji karczunkowej powstały wsie o mniejszych rozmiarach: Wiączyń Dolny i Wiączyń Nowy. Obie cechowały się jednostronną, luźną zabudową, zlokalizowaną po wschodniej (w przypadku Wiączynia Dolnego) lub po zachodniej stronie drogi (w przypadku Wiączynia Nowego), prowadzącej wprost do centrum Nowosolnej, a jednocześnie prostopadłej do osi kompozycyjnej nowo rozplanowanego Wiączynia Dolnego. W odniesieniu do wszystkich wsi rozłogi miały formę jednostronnych zagonów pasmowych, prostopadłych do drogi, przylegających bezpośrednio do zagród.

\section{Podsumowanie}

W artykule zaprezentowano wyniki badań poświęconych genezie, rozwojowi i zanikowi dawnych wsi Wiączyń Polny i Leśny. W świetle zgromadzonego materiału źródłowego udało się dokonać geograficzno-historycznej rekonstrukcji przemian osadnictwa na tle stosunków prawno-własnościowych, przeanalizować obraz zagospodarowania w całym okresie nowożytnym oraz zbadać rozplanowanie wsi i jego relacje przestrzenne z osadnictwem późniejszego pochodzenia. Wiączyń pojawił się w źródłach historycznych w XIV w., choć stosunki dziesięcinne mogą stanowić przesłankę pozwalającą przesunąć wstecz metrykę historyczną osady. Od początku XV w. pojawiają się zapiski wskazujące na funkcjonowanie podwójnego układu osadniczego (duplex). Obie wsie wchodziły w skład dóbr monarszych. Przez większość czasu swego istnienia pozostawały jednak w rękach prywatnych, a najdłużej były w posiadaniu rodu Lasockich, ówczesnych właścicieli miasta Brzeziny. Były to stosunkowo niewielkie osady, obejmujące nie więcej niż 8-12 łanów. Zamieszkiwane były przez chłopów pańszczyźnianych, stanowiących zróżnicowaną grupę społeczną pod względem powierzchni gospodarstw (byli wśród nich kmiecie półłanowi, zagrodnicy, chałupnicy, w tym rzemieślnicy). Pola podzielone były na niwy zgodnie z trójpolówką. Uprawiano głównie owies, żyto, pszenicę i groch. Działalność hodowlana miała marginalne znaczenie dla rozwoju gospodarczego wsi. W Wiączyniu 
zlokalizowana była karczma. Prowadzono również gospodarkę stawowo-rybną oraz eksploatowano pobliskie kompleksy leśne. Ważnym elementem zagospodarowania było założenie folwarczne, obejmujące dwór i zabudowania gospodarcze, w tym budynek browaru. Wiączyń Polny i Leśny miały charakter nieregularnych wsi placowo-drogowych lub wielodrożnych. Na początku XIX w. obie osady przestały istnieć $\mathrm{w}$ wyniku intensywnej akcji kolonizacyjnej zainicjowanej przez władze pruskie. Na ich miejscu powstały wsie: Nowosolna (która zastąpiła Wiaczyń Polny) oraz Wiączyń Dolny, Górny i Nowy (na obszarze Wiączynia Leśnego). Zabudowa dawnych osad została zlikwidowana, a ludność autochtoniczna przesiedlona. Nowe kolonie miały charakter czynszowy i były zasiedlone przez protestanckich osadników niemieckiego pochodzenia. Posiadały regularne rozplanowanie w postaci liniowej, jednostronnie lub obustronnie zabudowanych osi kompozycyjnych, którym najczęściej towarzyszył przyzagrodowy układ pasmowy rozłogów. Nowosolna przyjęła natomiast unikatową formę, opartą na układzie ośmiu promienistych dróg wychodzących z centrum układu.

Przeprowadzone badania stanowią egzemplifikację mikroskalowych studiów geograficzno-historycznych ukierunkowanych na rekonstrukcję sfery zagospodarowania i organizacji przestrzennej. Wpisują się również w nurt badań poświęconych zanikowi i sukcesji osadnictwa. Zdaniem autora wykonana analiza może stanowić źródło inspiracji poznawczych, szczególnie w aspekcie kontynuacji porównawczych studiów nad rozwojem społeczno-gospodarczym i przemianami rozplanowania wsi zaginionych na ziemiach polskich.

\section{Literatura}

Chilczuk M., 1970, Osadnictwo wiejskie Polski (Formy i układy przestrzenne), Warszawa.

Chłapowski K., Dygdała J., 2005, Prace edytorskie nad lustracjami dóbr królewskich XVI-XVIII w. po pótwieczu, „Studia Źródłoznawcze”, 43, s. 164-165.

Figlus T., 2014a, Wsie olęderskie w Polsce Środkowej. Uwagi na temat zróżnicowania morfogenetycznego na tle rozwoju osadnictwa, „Rocznik Łódzki”, 62, s. 143-159.

Figlus T., 2014b, Znaczenie czynników prawno-politycznych w procesie ksztaltowania wiejskiej sieci osadniczej dawnego województwa tęczyckiego i sieradzkiego w okresie przedrozbiorowym, ,Acta Universitatis Lodziensis. Folia Geographica Socio-Oeconomica", 17, s. 203-234.

Figlus T., 2015, Geneza i zmiany struktury spoleczno-gospodarczej osadnictwa wiejskiego $w$ dobrach królewskich na obszarze przedrozbiorowego powiatu szadkowskiego, „Biuletyn Szadkowski”, 15, s. 89-108.

Figlus T., 2016, Problem osad zaginionych na gruncie badań geograficzno-historycznych. Próba konceptualizacji teoretycznej $i$ wybrane zagadnienia metodyczno-empi- 
ryczne, „Acta Universitatis Lodziensis. Folia Geographica Socio-Oeconomica”, 25, s. $83-108$.

Heike O., 1979, 150 Jahre Schwabensiedlungen in Polen 1795-1945, Leverkusen.

Hochgeladen E., 1937, Neusulzfeld. Die Wege der Brüder in Polen, Łódź.

Kokotkiewicz P., 1984/1985, Nowosolna. Studium historyczno-ruralistyczne, Łódź -Warszawa.

Kossmann O.E., 1942, Die Anfänge des Deutschtums im Litzmannstäter Raum Hauländer und Schwabensiedlung, Leipzig.

Koter M., 1994, Rola wiejskich elementów morfologicznych w procesie ksztaltowania układu przestrzennego Łodzi, [w:] Koter M., Tkocz J. (red.), Zagadnienia geografii historycznej osadnictwa w Polsce, Toruń-Łódź, s. 63-88.

Kotkowski P., 1991, Struktury osadnicze i ludnościowe na terenach przyłaczonych do Łodzi z dniem 1.01.1988 r., praca magisterska napisana pod kierunkiem M. Kotera, maszynopis w archiwum Katedry Geografii Politycznej, Historycznej i Studiów Regionalnych Uniwersytetu Łódzkiego, Łódź.

Malinowska J., 2001, Studia osadnicze na obszarze powiatu brzezińskiego do połowy XVI wieku, Toruń.

Nowak T., 2003, Własność ziemska w ziemi łęczyckiej w czasach Władysława Jagietly, Łódź.

Schiewe M., 2000, Die südpreußischen Kolonien 1802-1806, „Altpreußische Geschlechterkunde", 30, s. 293-360.

Schöller H.A., 2009, Neu-Sulzfeld/Nowosolna 23.Mai 1801-17.Januar 1945, Ilustrierte historisch-geographische Erinnerungen an ein Dor fund seine Menschen, Erlangen.

Sobczak T., 1955, Zmiany $w$ stanie posiadania dóbr ziemskich $w$ województwie tęczyckim od XVI do XVIII wieku, „Roczniki Dziejów Społecznych i Gospodarczych”, 17, s. $163-193$.

Stępniewski M., Szambelan Z., 2009, Rozwój terytorialny Łodzi w świetle dokumentów i źródet kartograficznych, „Rocznik Łódzki”, 6, s. 37-50.

Tomczak A., 1957, Akta procesu mieszczan brzezińskich z dziedzicami $w$ Asesorii Koronnej 1791 r. o pogwatcenie stużacych im przywilejów miejskich, „Teki Archiwalne", 5, s. 334-355.

Wąsicki J., 1957, Ziemie polskie pod zaborem pruskim. Prusy Poludniowe 1793-1806. Studium historycznoprawne, Wrocław.

Witczak T., 1971, Lasocki Mikołaj, [w:] Polski słownik biograficzny, t. 16, s. 542-545.

Woźniak K.P., 2013, Niemieckie osadnictwo wiejskie między Prosna a Pilica i Wisła od lat 70. XVIII wieku do 1866 roku - procesy i jego interpretacja, Łódź.

Woźniak K.P, 2015, Pruskie osiedla liniowe w okolicach Łodzi i ich mieszkańcy w poczatkach XIX wieku, ,Acta Universitatis Lodziensis. Folia Geographica Socio-Oeconomica", 21, s. 101-117.

Zajączkowski S. i S.M., 1970, Materiaty do stownika geograficzno-historycznego dawnych ziem łęczyckiej i sieradzkiej do 1400 r., cz. 2, Łódź.

Zawadzki W., 1963, Polska stanisławowska woczach cudzoziemców, t. 1, Warszawa. 
Zimmermann K., 1915, Fryderyk Wielki i jego kolonizacja na ziemiach polskich, t. 1-2, Poznań.

Żytkowicz L., 1973, Lustracje dóbr królewskich XVI-XVIII wieku. Geneza i realizacja wydawnictwa, „Studia Źródłoznawcze”, 18, s. 191-197.

\section{Źródła}

Archiwum Główne Akt Dawnych w Warszawie (dalej: AGAD), Archiwum Skarbu Koronnego, dz. XLVI, ks. 103d, 104, 154, 173.

AGAD, Generalne Dyrektorium Departamentu Prus Południowych, sygn. 1008.

AGAD, Księgi ziemskie łęczyckie, ks. 6.

AGAD, Metryka Koronna, ks. 86, 161, 195; dz. XVIII, ks. 5.

AGAD, Zbiór kartograficzny, sygn. 326-14: I Spezial Karte von Saemtlichen zu den Starostey Ober-Wionczyn gehoerige Herrschafts und Unteranen Laendereyen, Zille, 1:5000, 1796.

AGAD, Zbiór kartograficzny, sygn. 326-17: II Spezial Karte von den Laendereyen der Koenig Starostey Nieder Wionczyn, Zille, 1:5000, 1796.

AGAD, Zbiór kartograficzny, sygn. 327-1: Plan zur Regulierung dieser im dem Königs. Domainen Amt Laznow, belegnen zu Dörfern Ober und Nieder Wionczyn, Künzel, 1:5000, 1803.

AGAD, Zbiór kartograficzny, sygn. 326-74: Situations-Plan von der Hofflage und Vorwerks Gebauden der Koenigs Starostey Ober Wionczyn, Zille, 1:5000, 1796.

AGAD, Zbiór kartograficzny, sygn. 287-15: Spezielle Charte von denen im Königs. Warschauer Kammer-Departement Domainen Amt Laznow zu angelegten Dörfern Ober und Nieder Wionczyn, nebst der davon establirten Colonie Neu Sulzfeld, Künzel, 1:15700, 1803

Biblioteka Uniwersytetu Warszawskiego, Gabinet rycin, GR 300, sygn. 299.

Boniecki A., Herbarz Polski, t. 13, Warszawa 1909.

Dziennik Urzędowy Województwa Łódzkiego Nr 14 z dnia 30 października 1987 r., Zarządzenie Nr 37/87 Prezydenta Miasta Łodzi z dnia 30 września 1987 r. w sprawie szczegółowego opisu granic miasta Łodzi.

Jana Łaskiego arcybiskupa gnieźnieńskiego Liber beneficiorum archidiecezji gnieźnieńskiej, wyd. J. Łukomski, J. Korytkowski, t. 2, Gniezno 1881.

Księgi sądowe tęczyckie od 1385 do 1419, cz. 1-2, [w:] Teki A. Pawińskiego, t. 3-4, Warszawa 1897.

Lustracja województw wielkopolskich i kujawskich 1564-1565, cz. 2, wyd. A. Tomczak, Bydgoszcz 1963.

Lustracja województw wielkopolskich i kujawskich 1616-1620, cz. 1, wyd. Z. Górski, R. Kabaciński, J. Pakulski, Wrocław 1994.

Lustracja województw wielkopolskich i kujawskich 1628-1632, cz. 3: województwa tęczyckie, brzesko-kujawskie, inowrocławskie i ziemia dobrzyńska, wyd. Z. Guldon, Bydgoszcz 1967.

Lustracja województw wielkopolskich i kujawskich 1789, cz. 3: województwa łęczyckie i brzesko-kujawskie, wyd. A. Tomczak, Z. Kędzierska, Warszawa-Poznań-Toruń 1977. 
Lustracja województw wielkopolskich i kujawskich 1659-1665, cz. 2: województwa sieradzkie, tęczyckie, brzesko-kujawskie, inowrocławskie i ziemia dobrzyńska, wyd. Z. Górski, J. Pakulski, A. Tomczak, Toruń 1996.

Matricularum Regni Poloniae summaria, cz. 2 i 4/1, wyd. T. Wierzbowski, Warszawa 1905-1910.

Monitor Polski, Nr 25, poz. 205, z dnia 4 IX 1987 r., Uchwała Rady Narodowej Miasta Łodzi nr XXVII/161/87 z dnia 29 VI 1987 r. w sprawie zmiany granic miasta Łodzi.

Niesiecki K., Herbarz Polski, wyd. J. Bobrowicz, t. 10, Lipsk 1845.

Polska XVI wieku pod względem geograficzno-statystycznym, wyd. A. Pawiński, Wielkopolska, t. 2, [w:] Źródła dziejowe, t. 13, Warszawa 1883.

Regestr diecezjów Franciszka Czaykowskiego, czyli właściciele ziemscy w Koronie 1783-1784, przypisy i wstęp K. Chłapowski i S. Górzyński, Warszawa 2006.

Volumina legum, t. 9, Kraków 1889.

\title{
The origins, development and disappearance of Wiączyń An attempt at geographic and historical reconstruction of settlement in the aspect of transformations of spatial planning and village layout
}

\author{
Summary
}

The paper presents the results of research concerning the currently non-existing villages of Wiączyń Polny and Leśny, where new Prussian colonies were created in the early $19^{\text {th }}$ century. The development of settlements in the Middle Ages was studied, and the modern-period development was analysed against the legal and ownership relations. Both villages first appeared in historical sources in the $14^{\text {th }}$ century and were part of the royal estate. For most of their history, they were leased by the nobility, with the longest-lasting being the Lasocki family. These were relatively small settlements, inhabited by serfs. Wiączyń had an inn and a grange, which included a mansion and farm buildings, including a brewery. The paper also attempts to reconstruct the layout of the village and to study the process of succession of settlement. Wiączyń Polny was an irregular roadand-square village, while Wiączyń Leśny was a multi-road village. As a result of Prussian colonisation, new villages were established in their place: Nowosolna, Wiączyń Dolny, Górny and Nowy. They were laid out in the form of regular linear villages, while Nowosolna took the form of a unique structure consisting of eight radial roads emerging from the centre.

Keywords: settlement, village, historical geography, morphogenesis, spatial planning, layout, spatial layout, Wiączyń.

Tomasz Figlus, dr

Uniwersytet Łódzki, Wydział Nauk Geograficznych, Katedra Geografii Politycznej,

Historycznej i Studiów Regionalnych, ul. Kopcińskiego 31, 90-142 Łódź

e-mail: tomasz.figlus@geo.uni.lodz.pl 